\title{
Introduction
}

\section{Introduction: Nordic Visions of International Migration and Refugee Law}

\author{
Thomas Gammeltoft-Hansen \\ Professor WSR in migration and refugee law, University of Copenhagen, \\ Copenhagen, Denmark \\ tgh@jur.ku.dk
}

Sarah Scott Ford

PhD Fellow, University of Copenhagen, Copenhagen, Denmark sarah.scott.ford@jur.ku.dk

This special issue of the Nordic Journal of International Law aims to broadly engage Nordic asylum and immigration regulation as an issue of international law. As an area of international law which both historically and today has held special significance in the Nordic countries, the issue presents a set of articles investigating the different domestic constructions and applications of international law, as well as Nordic responses to legal developments at the European and international levels. The articles moreover examine how Nordic countries and courts have responded to the growing role of international courts and supervisory mechanisms involved in migration and refugee law.

At a more general level, the issue further asks whether it is possible to identify a particular Nordic approach to or impact on international migration and refugee law. Historically, Nordic state practice and Nordic scholarship have both played a significant role in framing international legal developments ${ }^{1}$ as

1 Denmark, for example, was among the first countries to incorporate an explicit legislative provision in regard to 'safe third countries' in 1986 allowing for pre-procedure rejections at the 
well as the wider discipline of international refugee law. The last two decades, however, have also seen examples of Nordic countries pursuing evidently different policy paths and hence relationships to international migration and refugee law. Nordic countries also retain significantly different attachments to EU rules on free movement, asylum and immigration policy. Consequently, how does growing EU law in this area impact both existing Nordic cooperation as well as national asylum and immigration law in the Nordic countries?

This introduction offers some initial reflections in response to these questions, before introducing and setting the scene for the individual contributions.

\section{The Changing Terrain of International Migration and Refugee Law in a Nordic Context}

The backdrop and timing for a special issue on international migration and refugee law in a Nordic context is first of all empirical. Few other areas of international law have seen such significant transformations at the level of national implementation and, at least in recent years, demanded such extensive political attention across the Nordic countries. Traditionally seen as liberal frontrunners in regard to refugee rights and human mobility, Nordic countries were among the first to sign the ${ }_{1951}$ Convention Relating to the Status of Refugees - Denmark even chairing the negotiations. Similarly, the 1952 Nordic Passport Union and its subsequent protocols pioneered free movement and transnational residence and labour rights decades before other European countries. At the national level, Nordic aliens law has been similarly progressive, for instance introducing forms of complementary or humanitarian protection before these notions had taken shape on the international scene. ${ }^{2}$ Politically, Nordic countries have similarly remained important donors to the UN High Commissioner for Refugees, and active members of its Executive Committee.

Today, however, this picture has substantially changed. Over the past decades, all Nordic countries have introduced wide-ranging amendments to their asylum and immigration laws - generally in a more restrictive direction. In several cases, this has led Nordic countries to spearhead novel deterrence or reform measures in regard to, for example, temporary protection, family reunification, border closures, carrier

border; a concept which became known as 'the Danish clause' as it was replicated throughout Europe. M. Hunt, "The Safe Country of Origin Concept in European Asylum Law: Past, Present And future', 26:4 International Journal of Refugee Law (2014) pp. 500-535.

2 L. Feijen, 'Filling the Gaps? Subsidiary Protection and Non-EU Harmonized Protection Status(es) in the Nordic Countries', 26:2 International Journal of Refugee Law (2014) pp. 173-197. 
sanctions and third country partnerships. ${ }^{3}$ While the traditional liberal self-image may still play a role in some countries, ${ }^{4}$ the picture is increasingly one of Nordic states competing to pass legislation intended to deter prospective asylum-seekers and unwanted migration. ${ }^{5}$ Regulatory responses to recent events, including both the 2015 European asylum influx and the 2020 Covid-19 pandemic, have further significantly impacted both Nordic and European rules on free movement. For the past six years, national border controls have thus remained a semi-permanent fixture in large parts of the Nordic region, heavily affecting the lives of border communities and upending more than half a century of passport-free travel within the region.

The changing trajectories of Nordic asylum and immigration policy has not gone unnoticed. Different Nordic countries have in recent years found themselves in the international spotlight. This concerns not only media headlines, ${ }^{6}$ but also critical attention from actors charged with overseeing national implementation of international law. ${ }^{7}$ Multiple cases concerning Nordic asylum and immigration law have appeared before international courts and human rights bodies. While this forms part of a broader trend, the Nordic region features prominently in the case statistics. Both Denmark and Sweden are among the countries who have had the most non-refoulement claims decided by the UN

3 See for example the contribution by N. F. Tan in this issue.

4 R. Stern, 'Our Refugee Policy is Generous": Reflections on the Importance of a State's SelfImage', 33:1 Refugee Survey Quarterly (2014) pp. 25-43. L. Johannesson, 'Exploring the "Liberal Paradox" from the Inside: Evidence from the Swedish Migration Courts', 52:4 International Migration Review (2018), pp.1162-85.

5 T. Gammeltoft-Hansen, 'The Do-Gooders' Dilemma: Scandinavian asylum and migration policies in the aftermath of 2015', in A. de Bengy Puyvallée and K. Bjørkdahl (eds.), Do-Gooders at the End of Aid: Scandinavian Humanitarianism in the Twenty-First Century (Cambridge University Press, Cambridge, 2021).

6 For example, legislation enabling Danish authorities to confiscate valuable assets from asylum-seekers passed in 2016 attracted substantial international media attention, e.g. Editorial Team, 'Denmark's cruelty to Refugees', New York Times, 1 February 2016 <www. nytimes.com/2016/o2/o2/opinion/denmarks-cruelty-toward-refugees.html>, visited on 29 September 2021.

7 The UN High Commissioner for Refugees, for instance, has expressed clear critique of e.g. Norwegian legislation enabling rejections of asylum-seekers at the Russian border. UN High Commissioner for Refugees (UNHCR), 'UNHCR Observations on the Law Proposal "Prop. 16L (2015-2016) Endringer i utlendingsloven (innstramninger)", Instructions GI-12/2015, GI-13/2015 and 15/7814-EST". Circular "RS 2015-O13", and amendment to the "Immigration Regulation, $\S \S$ 17-18", NOAS, 23 December 2015, <www.noas.no/wp-content/uploads/2016/o4/UNHCRbrev-23-desember-2015.pdf>, visited on 6 October 2021; UN High Commissioner for Refugees (UNHCR), 'UNHCR observations regarding the processing of asylum claims from persons who have arrived to Norway from the Russian Federation', NOAS, 15 February 2016, <www.noas.no/ wp-content/uploads/2016/o4/UNHCR-brev-15-februar-2016.pdf>, visited on 6 October 2021. 
human rights treaty bodies. ${ }^{8}$ There have also been a significant number of cases in this area concerning Nordic countries before the European Court of Human Rights - in several instances establishing violations. ${ }^{9}$

In tandem with this development, the Nordic region has become an increasingly important testing ground for jurisprudential developments in this area by international courts and human rights bodies. As Sarah Scott Ford demonstrates in her article to this issue, Nordic litigation has led to several principled decisions by the UN human rights treaty bodies breaking new ground. Nordic cases have further helped frame interpretations across General Comments and the recommendations to states, the other outputs of these expert bodies. In its most recent Grand Chamber judgment against Denmark, the European Court of Human Rights similarly considered the developing practice of statutory waiting periods before refugees can apply for family reunification - a question on which the court openly admitted that no "clear guidance" was provided within the existing case-law. ${ }^{10}$

This Nordic backdrop for important case law development in this area is not simply a reflection of more international litigation. It is also a result of a growing political will among at least some Nordic countries to adopt novel measures in this area and consequently test the boundaries of international law. As Jens Vedsted-Hansen highlights in his contribution to this issue, the notion that legislative measures may entail a "procedural risk" of international courts and bodies subsequently finding Denmark in violation of its international obligations has become a mainstay in Danish asylum and immigration policy.

\section{2 \\ The Building of a Field: Nordic Scholarship on International Migration and Refugee Law}

The growing attention to asylum and immigration issues across Nordic countries is similarly reflected at the academic level. The past decades have seen not only an

8 B. Çali, C. Costello, and S. Cunningham, 'Hard Protection through Soft Courts? NonRefoulement before the United Nations Treaty Bodies', 21 German Law Journal (2020), pp. $355^{-384}$.

9 See e.g. Nunez v Norway, 28 June 2011, Application No. 55597/og; Butt v Norway, 4 December 2012, Application no. 47017/og; Kaplan and Others v Norway, 24 July 2014, Application no. 32504/11; Nv Finland, 26 July 2005, Application no. 38885/o2; N.a. v Finland, 14 November 2019, Application no. 25244/18; $N v$ Sweden, 20 July 2010, Application no. 23505/og; F.G. $v$ Sweden, 26 March 2016, Application no. 43611/11; Xv Sweden, 9 January 2018, Application no. 36417/16; Osman v Denmark, 14 June 2011, Application no. 38058/og; Biao v Denmark, 24 May 2016, Application no. 3859o/10.

10 M.A. v. Denmark, European Court of Human Rights, Application No. 6697/18, 9 July 2021, para. 178. 
expanding and more diverse body of legal scholarship but also a deepening institutionalisation of international migration and refugee law within Nordic universities and research institutions. Nordic law schools currently offer a range of specialised courses and teaching programmes focusing on anything from integration law, EU free movement and the law related to migration and climate change. Several dedicated university chairs and research groups have been established within this field in recent years, as well as expanding national ${ }^{11}$ and Nordic $^{12}$ research networks. These initiatives all help establish international migration and refugee law as a recognised sub-field within the legal discipline. As Pierre Bourdieu reminds us, standing as an academic field flows not simply from an expanding body of substantive scholarship, but also from the relative level of structural autonomy in relation to its wider environment, and the educational system within which it develops. ${ }^{13}$

A particular credit for this development is owed to the small, but persistent group of scholars who helped build Nordic academic interest in this area, and in turn shaped international migration and refugee law also beyond the Nordic context. Chief amongst these Nordic pioneers is arguably Atle Grahl-Madsen, professor of international law at first Uppsala and then Bergen University. As James Hathaway argues in his memorial lecture reprinted in this issue, Grahl-Madsen's importance for international refugee law can hardly be overstated. He may rightly be described as "the founder of the academic discipline of international refugee law". Even decades after his death, his works remain widely cited and have decisively shaped authorities' understanding of key concepts of refugee law around the world.

Another name which belongs in this group is Göran Melander, professor of law and founder of the Raoul Wallenberg Institute for Human Rights and Humanitarian Law in Lund, Sweden. Melander, together with Peter Nobel, early on adopted a distinctly Global South-oriented perspective on refugee law..$^{14}$ He was also the first to point to the problem of "refugees in orbit" resulting from the lack of international cooperation; a concept which became highly influential in the development of both national Nordic and European asylum law, including the Dublin System. ${ }^{15}$ While some Nordic countries, including

11 E.g., the Gothenburg / Lund / Uppsala Migration Law Network (GLUmiN) established in 2011, migrationlawnetwork.org/en/.

12 E.g., the Nordic Institute for Migration Law and Policy (NIM) established in 2016, www. samfunnsforskning.no/english/projects/the-nordic-institute-for-migration/

13 P. Bourdieu, 'Rethinking the State: Genesis and Structure of the Bureaucratic Field', 12:1 Contemporary Sociological Theory (1994) pp. 1-18.

14 G. Melander and P. Nobel (eds.), International Legal Instruments on Refugees in Africa (Scandinavian Institute of African Studies, Uppsala, 1979); G. Melander, 'Refugees and international cooperation', 15:1-2 International Migration Review (1981) pp. 35-41.

15 G. Melander, 'Refugees in Orbit', 16:25 A.W.R. Bulletin (Association for the Study of the World Refugee Problem) (1978) pp. 59-75. 
Iceland and Finland, experienced relatively lower numbers of asylum-seekers and non-Nordic immigrants during this period, Matti Pallonpää, professor at Helsinki University and later judge at the European Court of Human Rights, published his treatise on expulsion and international law as early as $1984 .{ }^{16}$ In Denmark, Jens Vedsted-Hansen, professor at Aarhus University, was one of the first scholars to take a sustained interest in this area, and early on identified the potential clash between refugee law and modern forms of migration control in a way that came to frame decades of subsequent scholarship. ${ }^{17}$

Between them, these individuals also helped train and inspire subsequent generations of Nordic scholars. Characteristic of this more recent scholarship is first and foremost the widening range of topics and specialisations. These works have zoomed in on specific challenges within the literature, such as credibility assessments, ${ }^{18}$ cessation of protection, ${ }^{19}$ national implementations of international law, ${ }^{20}$ or the need for international legal reform. ${ }^{21}$ Other

16 M. Pellonpää, Expulsion in international law: a study in international aliens law and human rights with special reference to Finland (Academia Scientiarum Fennica, 1984). For an early critique of Iceland's Aliens Act from a human rights perspective see R. Adalsteinsson, "The Current Situation of Human Rights in Iceland', 61 Nordic Journal of International Law (1992) pp.167-175.

17 J. Vedsted-Hansen, 'Völkerrechtliche aspekte der Sichtvermerskontrolle under the Sanktionen gegen Beförderungsunternehmen im hinblick auf das Asylrecht', 68:1/2 Die Friedens-Warte (1988) pp. 125-139; J. Vedsted-Hansen, 'Sanktioner mod transportselskaber med "inadmissible passengers"', 71:8 Juristen (1989) pp. 219-233. Another early Danish scholar in this area is Hans Gammeltoft-Hansen, professor and dean at the University of Copenhagen, who published an essay collection on international refugee law as early as 1984 . H. Gammeltoft-Hansen, Flygtningeret, (DJøF, 1984). In 1987, however, he took up a more practice-oriented position and consequently came to focus more on Danish administrative law.

18 E.g., R. Stern and H. Wikström (eds.), Migrationsrätt: Skyddsbehov och trovärdighet bedömning i asylärenden (Liber, 2016); H. Selim, J. Korkman, E. Pirjatanniemi and J. Antfolk, 'Asylum Claims based on Sexual Orientation: A Review of Psycho-legal Issues in Credibility Assessments', PsyArXiv, 8 June 2021, <doi.org/10.31234/osf.io/wsgv8>, visited on 6 October 2021.

19 E.g., J. Schultz, 'An end to asylum?: Temporary protection and the erosion of refugee status' in C. M. Jacobsen, M-A. Karlsen, S. Khosravi (eds.), Waiting and the Temporalities of Irregular Migration (Routledge, New York, 2020) pp. 170-185; N. F. Tan, "The End of Protection: The Danish 'Paradigm Shift'and the Law of Cessation', 9o:1 Nordic Journal of International Law (2021) pp. 6o-85.

20 E.g., J. Lindholm, Danske asylafgørelser: Baggrund, Kontekst, Analyse, (Jurist-og Økonomforbundets Forlag, Denmark, 2014); E. Nykanen, 'On the Lines of Demarcation and Their Significance-The Categories of Complementary Protection under the Finnish Aliens Act', 30:2 Nordic Journal of Human Rights (2012) pp. 148-173.

21 E.g., T. Einarsen, 'Mass Flight: The Case for International Asylum', 7:4 International Journal of Refugee Law (1995) pp. 551-578. 
studies have critically examined the relationship between international migration and refugee law and emerging issues or policy developments, such as climate change ${ }^{22}$ crisis politics ${ }^{23}$ or transnational asylum processing. ${ }^{24}$ Yet others focus on the interfaces between migration and refugee law and other legal regimes, such as EU law, ${ }^{25}$ international human rights law ${ }^{26}$ or international humanitarian law. ${ }^{27}$

A second characteristic of this next generation of Nordic scholarship is the emphasis on more interdisciplinary approaches, complementing the primarily doctrinal work of the early adopters. The theoretical outlook in this area is highly diverse, including evidence studies, ${ }^{28}$ institutional or justice theory, ${ }^{29}$ game

22 E.g., M. Cullen, 'Eaten by the sea': human rights claims for the impacts of climate change upon remote subnational communities', 9:2 Journal of Human Rights and the Environment (2018) pp. 171-193; M. Scott, Climate Change, Disasters and the Refugee Convention (Cambridge University Press, Cambridge, 2020).

23 E.g., R.T. Stern, 'When the ends justify the means?: Quality of law-making in times of urgency', 7:2 The Theory and Practice of Legislation (2019) pp. 85-100; V. Stoyanova and E. Karageorgiou (eds.), The New Asylum and Transit Countries in Europe during and in the Aftermath of the 2015/2016 Crisis (Brill, Leiden, 2018).

24 E.g., G. Noll, 'Visions of the exceptional: legal and theoretical issues raised by transit processing centres and protection zones', 5 European Journal of Migration and Law (2003) pp. 303-341.

25 E.g., G. Noll, Negotiating asylum: the EU acquis, extraterritorial protection and the common market of deflection (Brill, Leiden, 200o); J. Halleskov, 'The Long-Term Residents Directive: a fulfilment of the Tampere objective of near-equality', 7:2 European Journal of Migration and Law (2005) pp. 181-202; M.J. Elsmore and P. Starup, 'Union Citizenship-Background, Jurisprudence, and Perspective: The Past, Present, and Future of Law and Policy', 26:1 Yearbook of European law (2007) pp. 57-113; E. Blöndahl, 'Non-refoulement and Personal Circumstances in EU Law - the Icelandic Context" in K. Loftsdóttir, U.D. Skaptadóttir and S.B. Hafsteinsson (eds.), Mobility and Transnational Iceland (University of Iceland Press, Iceland, 2020).

26 E.g., T. Einarsen, 'The European Convention on Human Rights and the Notion of an implied right to de facto asylum, 2:3 International journal of refugee law (1990) pp. 361-389; V. Stoyanova, Human trafficking and slavery reconsidered: conceptual limits and states' positive obligations in European law (Cambridge University Press, Cambridge, 2017).

27 E.g., C.M. Bailliet, 'Assessing jus ad bellum and jus in bello within the refugee status determination process: contemplations on conscientious objectors seeking asylum', 20 Georgetown Immigration Law Journal (2005) pp. 337-384; E. N. Nen and E. Nykänen, Fragmented state power and forced migration: a study on non-state actors in refugee law (Martinus Nijhoff Publishers, Leiden, 2012).

28 E.g., I. Staffans, Evidence in European asylum procedures. (Martinus Nijhoff Publishers, Leiden, 2012); G. Noll, 'Junk science? Four arguments against the radiological age assessment of unaccompanied minors seeking asylum,', 28:2 International Journal of Refugee Law (2016) pp. 234-250.

29 E.g., L. Johannesson, In courts we trust: Administrative justice in Swedish migration courts (Doctoral dissertation, Department of Political Science, Stockholm University, 2017); E. Karageorgiou, 'Solidarity and sharing in the common european asylum system: The case of Syrian refugees', 17:2 European Politics and Society (2016) pp. 196-214. 
theory, ${ }^{30}$ legal anthropology, ${ }^{31}$ sociology ${ }^{32}$ political science, ${ }^{33}$ and management studies, ${ }^{34}$ to name but a few. Migration and refugee law, perhaps also more so than other areas of international law, has similarly attracted significant attention from scholars trained in other disciplines. ${ }^{35}$

Third and finally, Nordic research on international migration and refugee law has from the outset been characterised by a close relationship between scholarship and practice. Many key scholars have retained close connections to professional communities outside academia, taking time to engage in adjudicatory or investigatory functions within national legal structures, or serving as advisers to or in appointed positions within both national and international bodies and organisations. This type of 'revolving door' dynamics or 'double hatting' is equally characteristic for scholarship in this area also outside of the Nordic countries. ${ }^{36}$ Yet, it may be even more pronounced in the Nordic region where, at least historically, specialised appeals bodies were often specially designed to involve independent experts.

Significant contributions to Nordic scholarship on migration and refugee law have vice versa been made by individuals formally working in practice-oriented positions. ${ }^{37}$ Key Nordic textbooks on aliens and migration law continue

30 G. Noll, 'Risky Games? A Theoretical Approach to Burden-Sharing in the Asylum Field', 16:3 Journal of Refugee Studies (2003) pp. 236-252.

$31 \quad$ E.g. M. Janmyr and L. Mourad, 'Modes of ordering: labelling, classification and categorization in Lebanon's refugee response', 31:4 Journal of Refugee Studies (2018) pp. 544-565.

32 G. Oddson, H. Gunnlaugsson and J. F. Galliher, 'Runaway Icelanders: Globalization, Collapse and Crime', 9:9 The Arctic \& Antarctic International Journal of Circumpolar Socio-Cultural Issues (2015) pp. 29-57.

33 T. Gammeltoft-Hansen and N. F. Tan, "The end of the deterrence paradigm? Future directions for global refugee policy', 5:1 Journal on Migration and Human Security (2017) pp. 28-56; T. Gammeltoft-Hansen, Access to asylum: International refugee law and the globalisation of migration control (Vol. 77) (Cambridge University Press, Cambridge, 2011).

34 J. Palander, 'Self-initiated expatriates and their legal rights in Finland: Incentives and obstacles to recruitment and retention', in D. Habti and M. Elo (eds.), Global Mobility of Highly Skilled People (Springer, Cham, 2019) pp. 275-292.

35 See, as an example, the numerous articles engaging with law and legal issues in the Nordic Journal of Migration Research.

$36 \quad$ R. Byrne and T. Gammeltoft-Hansen, 'International refugee law between scholarship and practice', 32:2 International Journal of Refugee Law (2020) pp. 181-199.

37 E.g., P. Nobel, Refugee Law in the Sudan: with the Refugee Conventions and the Regulation of Asylum Act of 1974 (Nordiska Afrikainstitutet, 1982); H. Gammeltoft-Hansen, Flygtningeret (DJøF, 1984); M. Kjaerum, 'The concept of country of first asylum', 4:4 International Journal of Refugee Law (1992) pp. 514-530; M. Kjaerum, 'Refugee protection between state interests and human rights: where is Europe heading?', 24:2 Human Rights Quarterly (2002) pp. 513-536; V. Vevstad, 'Norges rolle i utviklingen av et felles europeisk asylsystem', 25:3 Nordic Journal of Human Rights (2007) pp. 282-294. 
to be either authored or co-authored by individuals with a practitioner background. ${ }^{38}$ Close collaboration and dynamic exchanges between scholars and practitioners is also reflected in the tradition for joint events. Based on an initial ad hoc seminar at the University in Copenhagen in 1979, the Nordic Asylum Law Seminars were always organised around this link and remains one of the longest running international conferences on refugee law, also attracting significant attendance from outside the Nordic region. ${ }^{39}$

It is an open question to what extent the changed political climates surrounding international migration and refugee law will impact the relationship between practice and scholarship in the Nordics. On the one hand, there are several examples of independent legal experts being excluded from adjudicatory or political fora in recent years. On the other hand, Nordic governments and political parties have in some cases more selectively sought to enlist academic expertise, also from outside the Nordic region, for the purpose of legal reforms or policy proposals on migration and refugee issues. As argued elsewhere, such dynamics are often closely linked to shifting policy agendas, and struggles over the relative importance of legal expertise are thus partly to be expected, not least in times when existing policy paradigms may be failing and new ones are being tested..$^{40}$ Vice versa, the severance of formal links between practice and scholarship may also prompt more critical perspectives on Nordic migration and refugee law and thus ultimately strengthen the structural autonomy and academic independence of this field of international law. ${ }^{41}$

\section{$3 \quad$ A Nordic Outlook on Migration?}

To what extent do these past works or the scholarly contributions in this special issue comprise a special Nordic orientation towards international migration

38 J. Aer, Ulkomaalaisoikeuden perusteet (Alma Talent, 2016); G. Wikrén and H. Sandesjö, Utlänningslagen med kommentarer, 12th edn. (Norstedts Juridik, 2020); Ø. D. Øyen (ed.), Lcerebok i Utlendingsrett, 2nd edn. (Universitetsforlaget, Oslo, 2018); E. Ersbøll, G. Homann, E. O. R. Khawaja, N. H. Larsen, U. I. Nørgaard, B. Spang and J. Vedsted-Hansen, Udlcendingeret, 4th edn. (Djøf Forlag, Copenhagen, 2020); C. Nilas, Migrationsjura (Djøf Forlag, Copenhagen, 2021).

39 The first of these was held in Bergen, June 1982, and co-organised by Atle Grahl-Madsen and Hans Gammeltoft-Hansen.

$40 \quad$ R. Byrne and T. Gammeltoft-Hansen, supra note 36.

41 For a recent such call, see R. Byrne, G. Noll and J. Vedsted-Hansen, 'Understanding the crisis of refugee law: Legal scholarship and the EU asylum system', 33:4 Leiden Journal of International Law (2020) pp. 871-892. 
and refugee law? This question relates to a prior debate in this journal as to whether a 'Nordic approach to international law' exists at all. ${ }^{42}$ Assessing the outcome of this debate, Astrid Kjeldgaard-Pedersen and Jakob v. H. Holtermann have argued that the search for such Nordicness in international law ultimately represents a "null result". 43 What may be identified, however, is a central tension between the Scandinavian legal realism approach to international legal scholarship, on the one hand, and a humanitarian activist approach, on the other. Nordic scholarship in the field of international migration and refugee law is similarly no stranger to such academic tensions. This may also reflect the way that migration and refugee law research has historically been regarded as a niche field within the national legal discipline ${ }^{44}$ regardless of the important position that many Nordic scholars in this field have held internationally.

Another point of common ground in this debate is that Nordic countries have often been rather reluctant to apply international law domestically, despite initial support for such international cooperation and the early ratification of international human rights and refugee treaties. ${ }^{45}$ Some of the contributions to the present issue appear to similarly notice this dichotomy between a formally supportive political stance to international law, on the one hand, and a more reluctant approach at the level of implementation, on the other. In her contribution, Rebecca Stern asks whether the incorporation of the Convention on the Rights of the Child has had an effect on asylum law and practice in the Nordic region. She finds that despite incorporation in three of the Nordic countries, the legal significance has been limited. Stern's findings suggest that theories on the effects of international treaties should be attentive to the existence of opposing national undercurrents in states' outlook on international law, even in areas of incorporation. In a similar vein, Matthew Scott and Russell Garner argue that although protection from disaster-related harms was pioneered by Sweden and Finland in the European context, the

42 See the Special Issue edited by A. Kjeldgaard-Pedersen, 'A Nordic Approach to International Law?', 85:4 Nordic Journal of International Law (2016).

43 J. v. H. Holtermann and A. Kjeldgaard-Pedersen, 'International Law from a Nordic Perspective', in P. Hilpold (ed.), European International Law Traditions (Springer, Cham, 2021) p. 253 .

44 A point initially made by Atle Grahl-Madsen himself. We are indebted to Hans GammeltoftHansen for relaying this information.

45 J. K. Schaffer, "The Self-Exempting Activist: Sweden and the International Human Rights Regime', 38:1 Nordic Journal of Human Rights (2020) pp. 40-6o; J. Christoffersen and M. Rask Madsen, 'The End of Virtue? Denmark and the Internationalisation of Human Rights', 8o:3 Nordic Journal of International Law (2011) pp. 257-77; M. Wind, 'Do Scandinavians Care about International Law? A Study of Scandinavian Judges' Citation Practice to International Law and Courts', 85:4 Nordic Journal of International Law (2016) pp. 281-302. 
transformative potential of these legal instruments is tempered by the actual judicial practice, where there is only scant consideration of disaster displacement claims.

Another starting point for talking about a common Nordic approach to migration and refugee law is the role and legacy of the $195^{2}$ Nordic Passport Union, pioneering free movement in the region. While this regime continues to provide additional rights for Nordic citizens, free movement cooperation, however, has today effectively merged with the European Schengen Acquis. As Heinikoski and Hyttinen point out in this special issue, the different relationships towards the EU across the Nordics raises the question whether growing EU harmonisation on asylum and migration law has come at the expense of a more Nordic approach to international migration and refugee law. Sweden and Finland are the only Nordic countries who remain fully bound by EU law in this area, as well as the jurisdiction of the Court of Justice of the European Union. Yet, this has not prevented either country from adopting more unilateral measures intended to deter asylum-seekers, in some cases specifically referencing the Common European Asylum System (CEAS) in the process. ${ }^{46}$ Vice versa, due to participation in both the Dublin System and the Schengen Acquis, Norway has historically sought to closely align its national legislation with relevant EU law. ${ }^{47}$ Denmark, finally, arguably holds the most unique position when it comes to EU law in this area, combining a general opt-out on justice and home affairs with parallel agreements and a protocol to similarly enable participation in both Dublin and Schengen. The intricate contours between each of these policy areas, as well as other parts of EU law, such as free movement principles, has in some cases made Denmark's relationship to EU cooperation in this area highly complicated and prompted several different rule sets in regard to e.g. family reunification at the national level. ${ }^{48}$ At the same time, however, there is little doubt that the legal opt-out has afforded Denmark a wider regulatory space compared to other EU countries, and that Denmark has been willing to make use of this. ${ }^{49}$

46 O. Wahlbeck 'To Share or Not to Share Responsibility? Finnish Refugee Policy and the Hesitant Support for a Common European Asylum System,' 17:3 Journal of Immigrant \& Refugee Studies (2019) p. 307.

47 V. Vevstad and C. Mysen, 'Normative European Jurisprudence in a Refugee and Migration Context', Rapport-Institutt for samfunnsforskning (2011).

48 T. Gammeltoft-Hansen, 'Retsforbeholdet: Et forbehold ude af kontrol?', 81:3 Økonomi og Politik (2008) pp. 35-44.

49 T. Gammeltoft-Hansen and S. Scott Ford, 'Danish Immigration Law', in P. Aagaard Nielsen and J. Olsen (eds.), Constitutional and Administrative Law in Denmark (Hans Reitzel, Copenhagen, 2021). 
The question of a Nordic approach to international migration and refugee law may finally be viewed through the lens of particular events or challenges impacting the entire region. The spike in European asylum-seekers in 2015/16 on the one hand saw internal border controls re-introduced, without a coordinated regional approach. On the other hand, the period since 2015 has arguably also seen a closer alignment of national policies. Most countries have adopted more restrictive approaches and in several cases openly copied legislative measures from one another. ${ }^{50}$ Likewise, the response to the Covid-19 pandemic did not see any significant regional coordination effort in regard to border closures, migration or asylum measures. As Saila Heinikoski and Tatu Hyttinen argue in their article, it may possibly have led to further distancing through the emphasis on national priorities - only time will tell.

Today, the Nordic region stands out as a playing field for broader legal discussions on the development and interpretation of international migration and refugee law. In this context, the European refugee protection crisis was a significant turning point, where the Nordic states responded with significantly restrictive measures that had the goal of deterring asylum seekers. The recent turn towards the cessation of refugee status in Norway and Denmark is a case in point. In both countries a lower threshold for ending protection granted on the basis of general human rights law is applied, as compared to the standards for cessation following from the 1951 Refugee Convention and EU law. ${ }^{11}$ In contrast, Swedish and Finnish responses, while also representing a significant U-turn from past periods, ${ }^{52}$ appear less confrontational vis-à-vis international and EU law.

Norway and Denmark have further pursued legal measures which might be seen as challenging dominant interpretations of international law. For instance, the 2015 change to the formulation of 'safe third country'53 in the Norwegian

$50 \quad$ Gammeltoft-Hansen, supra note 6.

$5^{1} \quad$ N. F. Tan, 'The End of Protection: The Danish "Paradigm Shift" and the Law of Cessation', 9o:1 Nordic Journal of International Law (2021) pp. 1-28; J. Schultz, 'An End to Asylum? Temporary Protection and the Erosion of Refugee Status', in C. M. Jacobsen, M. Karlsen and S. Khosravi (eds.), Waiting and the Temporalities of Irregular Migration (Routledge, London, 2020); J-P. Brekke, J. Vedsted-Hansen, and R. Stern, 'Temporary Asylum and Cessation of Refugee Status in Scandinavia Policies, Practices and Dilemmas', European Migration Network Norway Occasional Papers, 2020, <www.udi.no/globalassets/global/european-migration-network_i/ emn-norway-papers/emn-occasional-paper-temporary-asylum-and-cessation-of-refugeestatus-in-scandinavia-2020.pdf $>$, visited on 6 October 2021.

$5^{2}$ R. Stern, 'When the ends justify the means? Quality of law-making in times of urgency', 7:2 Theory and Practice of Legislation (2019) pp. 85-100.

53 Legal innovations in this domain is not completely new to the region. While Norway is testing the bounds of the 'safe third country' rule today, Denmark was one of the first countries to incorporate an explicit legislative provision in regard to "safe third countries"' 
Immigration Act excluded asylum seekers who had travelled from Russia from refugee status determination, raising questions of compatibility with both the 1951 Refugee Convention and the EU Dublin rules. ${ }^{54}$ Another recent example is the Danish government's legal steps towards establishing a mechanism for the transfer of asylum seekers outside Europe. ${ }^{55}$ While it started out as a political vision for reforming the EU asylum system, its current unilateral form may well be seen to challenge it instead, as Nikolas Tan explains in his article to this issue.

While these examples relate to frontline discussions that generate headlines and relate to the overall politicisation of this issue area, other Nordic issues of migration law rarely make headlines nor fit this restrictive trend. Thomas Gammeltoft-Hansen and Sune Klinge explore two such examples in their contribution to this special issue, surrounding the legal regulation of asylum seekers in Greenland and Svalbard. As they point out, the more liberal rules applying to these arctic territories at first glance represent a striking anomaly to the more restrictive rules in the two countries. At the same time, however, both territories lack a national legal framework for ensuring refugees and other aliens economic and social rights on par with those applying in the respective parent states. Both cases point to the existence of regulatory practices at the margins of the region, which sit uneasily with existing narratives of Nordic migration and refugee law.

\section{Summary of Articles}

This special issue of the Nordic Journal of International Law presents six fulllength articles and two shorter pieces. The contributions all engage Nordic asylum and immigration regulation as an issue of international or EU law but vary in terms of subject area and geographical focus. The special issue begins with a series of three comparative articles, focusing on cross-cutting issues including incorporation, human rights litigation and free movement. This is followed by three articles that take a more a temporal perspective - including a historical look at the legislative and judicial strategies taken by Denmark in regard to migration and refugee law, and the emergence of new protection categories for individuals displaced by disasters and climate change in Sweden and Finland.

\footnotetext{
in 1986, a concept which that became known as "the Danish clause"' as it was replicated throughout Europe. See, supra note 1.

54 Lov om endringer i utlendingsloven, LOV-2015-11-20-94.

55 See further N. F. Tan in this special issue.
} 
The final two contributions include a legal analysis of the recent Danish proposal to enable third country asylum processing as well as a memorial lecture for the Norwegian scholar Atle Grahl-Madsen.

The first article, by Rebecca Stern, asks what incorporation of the Convention on the Rights of the Child has meant for asylum-seeking children in the Nordic region. As she points out, this issue remains somewhat of a puzzle. Nordic countries are normally considered to hold children's rights in high regard but have also been repeatedly criticised for foregoing the rights of the child in the asylum context. Drawing on the wider literature on incorporation of human rights treaties, she identifies three common expectations in terms of the impact of incorporation for effective human rights implementation: i) the strengthening of the status of the treaty in domestic law; ii) the invocation by domestic courts and government institutions; and iii) the enhanced visibility and awareness of the treaty's rights. Yet, analysing legislative developments across each of the Nordic countries during and following the "refugee crisis" Stern finds that the actual impact of CRC incorporation in regard to each of the three areas is generally limited and far from support the expectations within the general literature.

The following article, by Sarah Scott Ford, takes a closer look at the increasing involvement of UN human rights treaty bodies on claims lodged by asylum seekers and migrants against the Nordic countries. This litigation has spurred a form of quasi human rights oversight in a legal domain where states have historically been largely shielded from international adjudication. While broader changes have prompted these expert bodies to play a more pronounced role in this area, Scott Ford argues that the prominence of Nordic cases must be seen on the backdrop of national contexts as shaped by both strategic litigation and specialised appeals systems. The question then remains what increasing treaty body oversight implies for Nordic asylum systems. While the committee views are formally non-binding and target sensitive political issues, Scott Ford finds that in at least some Nordic countries they nonetheless have significant quasi-judicial effects.

The third article, by Saila Heinikoski and Tatu Hyttinen, considers a highly topical issue, namely the impact of Covid-19 on the free movement regime in the Nordic countries. As they and this introduction points to, free movement in the Nordic region represents a historical vision of regional borderlessness, which predates the EU free movement regime. In this perspective, what do the recent restrictions to free movement and the reintroduction of border control in the context of the Covid-19 pandemic and the 2015 "refugee crisis" mean for the regulation of free movement in the Nordic region vis-àvis the EU? Heinikoski and Hyttinen's contribution highlights how the four 
continental Nordic states took different paths in the wake of the pandemic, interpreted EU rules differently and instigated restrictions that were at times questionable from an EU law and domestic legal perspective. They argue that these responses to crisis may, on the one hand, potentially disrupt the special mobility in the region beyond the pandemic, by eroding the symbolic value of Nordic borderlessness. On the other hand, they suggest that current struggles to find common approaches at the EU level may potentially reinforce the importance of Nordic free movement.

In the following article, Matthew Scott and Russell Garner explore the innovative legal protection categories introduced by Sweden and Finland to accommodate the protection needs of individuals displaced by disasters and climate change. These provisions emerged from ideals of human rights and international solidarity, and it is therefore worth considering whether these norms may serve as an inspiration also beyond the Nordic context, and inspire legal practices responding to such displacement challenges. Scott and Garner set out by analysing the historical trajectories of these provisions and jurisprudence, but ultimately find that the transformative potential of these legal instruments is remarkably absent in the actual judicial practices. They further suggest that relying on these historical experiences may engender conceptual confusion and ultimately more restrictive interpretations. As such, they argue that these once pioneering judicial experiments should be added to the collective evidence base rather than serve as something to directly emulate.

Jens Vedsted-Hansen equally takes a historical perspective in his contribution, which addresses Denmark's legislative and judicial strategies in the immigration and asylum domain. As he argues, the changing position of Denmark on these matters reflect a broader shift in Denmark's relationship to international law. The article highlights three issue areas as particularly illustrative of Denmark's cross-cutting strategy to apply a more managerial approach to its international obligations when it comes to asylum and immigration policy: i) expulsion; ii) family reunification; and iii) the national institutional framework for refugee status determination. Vedsted-Hansen relates these strategies to a broader human rights scepticism in Denmark, and tentatively suggests that the outlook on international law when it comes to asylum and immigration policy has the potential to spill over into other policy areas - both politically and in the academic discourse.

The last full-length article, by Thomas Gammeltoft-Hansen and Sune Klinge, investigates the legal regulation of asylum seekers in Nordic overseas territories and not fully sovereign states. With the arrival of both rejected asylum seekers and recognised refugees to Greenland and Svalbard, the article analyses the unusual legal frameworks and histories governing these Nordic territories. 
At the outset, these legal frameworks stand out as curious anomalies against more restrictive policies in Denmark and Norway, where the case of Greenland appears as a regulatory time capsule of more liberal Danish migration policies and Svalbard essentially represents an open border policy. At the same time, however, there is an absence of national legal structures, leading to an absence of domestic protection and welfare structures. The Arctic territories thus serve as useful counterpoints to the broader debate on 'externalisation' and 'outsourcing' of asylum and migration control. In both the Nordic cases, legal differentiation takes place within state territory and displaces national rather than international law.

The penultimate contribution, by Nikolas Tan, investigates the recent legal basis proposed by Denmark providing for the externalisation of asylum. The analysis outlines the political vision contained in its different iterations and identifies a shift from the ambition to lead or spark EU efforts in this direction, towards a more unilateral attempt to limit obligations and deter future asylum seekers. Tan further reflects on the legal and political implications, should this proposed vision be implemented, including the possible litigation that might emerge from pursuing such a legally creative but ultimately isolationist position in a European context.

The final contribution, by James Hathaway, bookends the special issue with a slightly edited memorial lecture, which was originally delivered at the 2013 Nordic Asylum Law Conference in Bergen, Norway. Hathaway reflects on the profound and multifaceted impact of Atle Grahl-Madsen's work for the academic discipline of international refugee law. From a personal perspective and reflecting on his own academic indebtedness to this pioneering scholar, Hathaway lists six major contributions that Grahl-Madsen made to the field. Amongst those, he points to the Norwegian professor's unwavering academic integrity and his lasting impact on both the practice and study of international refugee law.

\section{Acknowledgement}

Thomas Gammeltoft-Hansen is professor wSR in migration and refugee law and Sarah Scott Ford is a PhD candidate, both at iCourts Center of Excellence for International Courts, Faculty of Law, University of Copenhagen. The editors would like to thank the anonymous reviewers to each article for their significant input as well as Leonora Kleppa Stærfeldt for her editorial assistance in compiling this special issue. 